\title{
OS PRINCÍPIOS DO DIREITO CIVIL LUSO E BRASILEIRO E A FRATERNIDADE NA DECLARAÇÃO UNIVERSAL DOS DIREITOS HUMANOS
}

\author{
Nara Pinheiro Reis Ayres de Britto ${ }^{113}$ \\ Bryan Phillip de Jongh Martins ${ }^{114}$
}

\begin{abstract}
RESUMO: O presente trabalho tem como objeto a influência e consonância da fraternidade proposta pelo artigo "I" da Declaração Universal dos Direitos Humanos dentre os princípios norteadores do direito civil brasileiro e do direito civil português. A Constituição da República Federativa do Brasil de 1988 e a Constituição da República Portuguesa de 1976 trazem em seu preâmbulo a fraternidade como uma meta social a ser cumprida, o que aproxima ainda mais a aplicação da disposição universal no direito civil de cada um dos países. No Brasil, os três princípios do ordenamento civil são a eticidade, a sociabilidade e a operacionalidade; em Portugal são nove: da personificação jurídica do ser humano, do reconhecimento dos direitos da personalidade, da igualdade da pessoa humana perante a lei e na lei, do reconhecimento da família como instituição fundamental, da autonomia da vontade ou da autonomia privada, da consagração da responsabilidade civil, da propriedade privada, do reconhecimento ao direito sucessório a todos os herdeiros e do reconhecimento da personalidade jurídica às pessoas coletivas. Todos estes princípios, de certa forma, recebem da Declaração Universal dos Direitos Humanos um norteador que direciona as relações civis, cada um de seu modo, cujo fim ensejado é a efetivação da fraternidade social. Como principal marco teórico adota-se a obra de Alexy, "Teoria dos Direitos Fundamentais", bem como esparsa literatura relacionada à temática do trabalho. O objetivo do trabalho é relacionar, princípio a princípio, os atributos fraternais incutidos na aplicação da lei civil e, como resultado, pode-se perceber a influência desse objetivo fraternal em cada um dos princípios civis.
\end{abstract}

Palavras-chave: Direito Civil; Direitos Humanos; Fraternidade; Princípios.

\section{SUMÁRIO}

INTRODUÇÃO; 1. OS PRINCÍPIOS DO CÓDIGO CIVIL BRASILEIRO E PORTUGUÊS E A FRATERNIDADE HUMANA; 2. OS PRINCÍPIOS FUNDAMENTAIS NORTEADORES DO DIREITO CIVIL PORTUGUÊS; CONCLUSÕES FINAIS; REFERÊNCIAS BIBLIOGRÁFICAS.

\footnotetext{
${ }^{113}$ Doutoranda em Direito Ciências Jurídicas pela Universidade Autónoma de Lisboa (Portugal), UAL, Mestre em Direito Ciências Jurídicas pela Universidade Autónoma de Lisboa (Portugal), UAL, Bacharel em Direito pelo Centro Universitário de Brasília - UNICEUB, professora orientadora do Centro Brasileiro de Estudos Constitucionais - CBEC Universitário, do Centro Universitário de Brasília - UniCEUB membro colaboradora do Instituto de Advogados do Distrito Federal - IADF, advogada, sócia de capital do escritório Ayres Britto Consultoria Jurídica e Advocacia, conferencista, autora de livros e artigos jurídicos.

114 Bacharelando em Direito pelo Centro Universitário de Brasília - UNICEUB, Diretor Institucional do Instituto Victor Nunes Leal - IVNL, pesquisador na área de Direito Constitucional e Digital, autor de livros e artigos jurídicos.
} 


\section{INTRODUÇÃO}

O presente artigo pretende abordar a relação entre a fraternidade atribuída pelo artigo "I" da Declaração Universal dos Direitos Humanos (DUDH) e os princípios dos códigos civis luso e brasileiro.

Denota-se, em sede introdutória, que a fraternidade expressa, tanto na Declaração Universal dos Direitos Humanos quanto nos preâmbulos das constituições do Brasil e de Portugal, se apresenta como uma manifestação que permeia toda a função social, em esferas públicas e privadas, como um objetivo social final, cujo resultado seria uma sociedade com o adjetivo fraterno.

O direito civil brasileiro é dotado de três princípios constantes do Código Civil de 2002, vigente, quais sejam: a eticidade, a sociabilidade e o da operabilidade. Todos tangem para efetivação, de certa forma, de uma sociedade fraternal.

Já o direito civil português, possui nove princípios inerentes ao Código Civil de 1966, vigente, sendo eles: da personificação jurídica do ser humano, do reconhecimento dos direitos da personalidade, da igualdade da pessoa humana perante a lei e na lei, do reconhecimento da família como instituição fundamental, da autonomia da vontade ou da autonomia privada, da consagração da responsabilidade civil, da propriedade privada, do reconhecimento ao direito sucessório a todos os herdeiros e do reconhecimento da personalidade jurídica às pessoas coletivas. Em um espectro mais amplificado, os princípios do código civil português também conduzem, em sua efetivação, ao estado de fraternidade.

Por tanto, adiante, pretende-se demonstrar a relação entre esses princípios e a fraternidade.

\section{OS PRINCÍPIOS DO CÓDIGO CIVIL BRASILEIRO E PORTUGUÊS E A FRATERNIDADE HUMANA}

O artigo "I" da Declaração Universal dos Direitos Humanos dispõe que as relações humanas devem se pautar pelo espírito de fraternidade (ASSEMBLÉIA GERAL DA ONU, 1948), assim como a Constituição da República Federativa do Brasil, de 1988, e a Constituição da República Portuguesa, de 1976, também mencionam a fraternidade em seus preâmbulos, como um objetivo social elementar. 
A partir da ideia de Alexy, pode-se dizer que existem várias formas de diferenciar regras de princípios; a mais comum delas é a generalidade. As normas dotadas de um nível de generalidade mais alto são consideradas princípios, enquanto as que possuem nível mais baixo são regras comuns (ALEXY, 2011, p. 87). Além disso, a diferenciação entre a norma e o princípio não se percebe apenas pelo caráter de seu grau de generalidade, se denota também pelo aspecto qualitativo, aspecto que o autor entende como correto. $\mathrm{O}$ critério crucial para a caracterização de um princípio se dá pelo dever empregado por essa norma de promover em máximo grau a realização de algo, respeitados os parâmetros fáticos e legais existentes (ALEXY, 2011, p. 90).

Neste caso, quando falamos em princípios, podemos auferir que o fim buscado está relacionado à busca intrínseca pela prevalência de uma sociedade pautada pelas intenções fraternas. Portanto, neste capítulo, busca-se demonstrar a relação entre os princípios dispostos no Código Civil e a busca por uma sociedade fraterna, como propõem a Constituição da República Federativa do Brasil de 1988 e a Declaração Universal dos Direitos Humanos de 1948.

Cabe ressaltar de antemão que enquanto no Brasil existe uma maior concentração de princípios na esfera constitucional, existindo apenas três princípios inseridos no Código Civil, em Portugal os princípios instituídos pelo ordenamento civil são bem mais numerosos.

\subsection{A Fraternidade e os Princípios do Código Civil Brasileiro}

Os princípios contidos no Código Civil Brasileiro de 2002 podem ser facilmente relacionados com o que se entende como convívio fraterno. Obviamente, as relações humanas não se consubstanciam apenas pelo contemplado conteúdo do direito civil; contudo, faz-se uma delimitação negativa, restringindo o recorte aqui abordado ao âmbito do direito civil.

Os três princípios presentes no Código Civil de 2002 são: O princípio da eticidade, o da sociabilidade e o da operabilidade. Todos possuem, em diferentes graus, relação com o que se percebe como elementos basilares da efetivação da fraternidade como fim implícito no direito civil. Ressalta-se que o direito civil brasileiro é permeado pela Constituição da República Federativa do Brasil de 1988, que coloca uma farta gama de princípios que devem ser aplicados em todo o ordenamento jurídico brasileiro, mas este capítulo delimita- 
se ao âmbito da aplicação e efetivação da fraternidade presente na DUDH no direito civil brasileiro através de seus princípios.

\subsection{O Princípio da Eticidade}

A relação entre a "eticidade" e a fraternidade se denota como um dos diversos princípios cuja proposta de dever ser se consagra como destino, resultando em uma sociedade fraterna.

Quando falamos a respeito de "eticidade", faz-se mister entender o que significa essa palavra. "Eticidade" se origina da palavra "ética"; no Dicionário Escolar da Língua Portuguesa de 1983, "ética" significa "Parte da filosofia que estuda os deveres do homem para com Deus e a sociedade: deontologia: ciência da moral." (BUENO, 1983, p. 462).

Ao observarmos a etimologia da palavra "ética", percebemos que ela está elencada à palavra "moral”, e ambas se referem a condutas do homem. (REINEHR, 2013).

Sobre o princípio da eticidade, o Código Civil de 2002 se afastou do "tecnicismo institucional" herdado do Direito Romano, que era extremamente formal, e tratou de dar reconhecimento aos valores éticos em todo o ramo do Direito Privado. (TARTUCE, 2011, p. 45).

Destarte, ao ter como princípio basilar o da "eticidade", ele privilegiou a "ética", como fundamento e orientação primordial a ser seguida pelo aplicador da norma nas relações privadas. (HENTZ, 2006).

Sobre o princípio da eticidade, Alexandre dos Santos Cunha afirma que tal princípio tem como objetivo a valorização do indivíduo perante a sociedade, e esse princípio se efetiva por meio da aplicação dos princípios constitucionais, e, indubitavelmente, por meio da dignidade da pessoa humana. (CUNHA, 2002, p. 260).

Afirma, ainda, que apesar de o princípio da dignidade da pessoa humana estar inserido na Magna Carta, sua origem e sua concretização advêm do direito privado. (CUNHA, 2002, p. 260).

Sobre o que é ser ético, o jurista Carlos Ayres Britto afirma: "O fato é que a ética leva o indivíduo a um estado de centralidade, a ter orgulho de si 
mesmo e a ter uma personalidade bem formada que, do individual, passa para o coletivo". (BRITTO, 2013).

Fazendo um paralelo do "ser ético", acima conceituado, com o contexto do estudo em questão, o "indivíduo" supramencionado pode ser entendido como o operador do Direito a se valer da norma positivada no Código Civil de 2002. Esse "ser ético", constituído de um estado de centralidade e orgulho de si mesmo, interage com a coletividade agindo com ética, moral e objetiva o bem comum social ao aplicar as normas gerais do Direito Civil em si.

Nas palavras de José Augusto Delgado, "interpretar as regras do Código Civil com base em princípios éticos é contribuir para que a idéia de justiça aplicada concretamente torne-se realidade". (HENTZ, 2006).

Deveras, podemos perceber a valorização do homem sendo concretizada no momento em que a lealdade e a confiança começam a fazer parte das relações privadas.

Esse contexto de segurança se concretiza quando o julgador, e aplicador do Direito, pode analisar subjetivamente a controvérsia judicial em questão e buscar uma solução jurídica mais igualitária a ser aplicada ao caso concreto. Esse cenário acaba por gerar um distanciamento das formalidades jurídicas impostas pela legislação civil de 1916.

Destarte, o princípio da eticidade é caracterizado como o que garante a aplicação da boa-fé objetiva em todas as relações civis. Exemplo disso está nas relações contratuais, onde ambas as partes dos contratos devem agir de acordo com a boa-fé. (BERTOCCO, 2008).

Sobre a legislação brasileira, o princípio da eticidade está contemplado no Código Civil de 2002, quando este privilegia os institutos da boa-fé, da moral e dos bons costumes em vários de seus artigos ${ }^{115}$, e, dessa forma, deixa o

\footnotetext{
115“'Art. 113. Os negócios jurídicos devem ser interpretados conforme a boa-fé e os usos do lugar de sua celebração." (grifo nosso).

"Art. 164. Presumem-se, porém, de boa-fé e valem os negócios ordinários indispensáveis à manutenção de estabelecimento mercantil, rural, ou industrial, ou à subsistência do devedor e de sua família." (grifo nosso).

"Art. 187. Também comete ato ilícito o titular de um direito que, ao exercê-lo, excede manifestamente os limites impostos pelo seu fim econômico ou social, pela boa-fé ou pelos bons costumes." (grifo nosso).

"Art. 309. O pagamento feito de boa-fé ao credor putativo é válido, ainda provado depois que não era credor." (grifo nosso).

"Art. 689. São válidos, a respeito dos contratantes de boa-fé, os atos com estes ajustados em nome do mandante pelo mandatário, enquanto este ignorar a morte daquele ou a extinção do mandato, por qualquer outra causa." (grifo nosso).

“Art. 1.638. Perderá por ato judicial o poder familiar o pai ou a mãe que:
} 
aplicador do Direito à vontade para interpretar as normas jurídicas abertas de acordo com a ética, moral, boa-fé e bons costumes. (REINEHR, 2013).

A boa-fé também é um dos motivos pelos quais a lei civil brasileira foi alterada em 2002. Atualmente, ela é amparada pelo princípio da eticidade e inspira a ordem jurídica para a aplicação justa das normas já existentes. Ela é um dos princípios que mais influenciam todo o ordenamento jurídico brasileiro, principalmente o Direito Privado.

Ao citar a conceituação de Miguel Reale, Flávio Tartuce esclarece que o princípio da eticidade cuida da valorização ética e da boa-fé, de acordo com a boa-fé objetiva, no plano da conduta de lealdade das partes. (TARTUCE, 2011, p. 23$)$.

Assim, de acordo com o Código Civil de 2002, a boa-fé objetiva teria como função interpretar os negócios jurídicos em geral; tal aplicação está consagrada no artigo 113 do Código Civil de 2002.

Ademais, a boa-fé objetiva ainda atua como forma de controle das condutas humanas, uma vez que quando violada, sua consequência pode acarretar em abuso de direito, o que é uma modalidade de ilícito, como se depreende do artigo 187 do Código Civil de 2002.

Cabe esclarecer que além da função de interpretar e controlar as condutas humanas, a boa-fé ainda tem a função de integrar absolutamente todas as fases da relação contratual, como se pode observar do disposto no art. 422 do Código Civil de 2002.

Portanto, diante do exposto, há de se perceber uma relação entre o princípio da eticidade, pela boa-fé nas relações civis, e a busca por uma sociedade fraternal no Brasil. As boas práticas em âmbito civil são de fundamental importância para que em últimas circunstâncias se alcance a fraternidade presente no artigo "I" da Declaração Universal dos Direitos Humanos (ASSEMBLÉIA GERAL DA ONU, 1948).

\subsection{Princípio da Sociabilidade}

Quando tratamos de sociedade fraterna, tem-se incutido o necessário convívio social inerente à condição humana enquanto animal social. Afinal, não

III - praticar atos contrários à moral e aos bons costumes;" (grifo nosso). 
há fraternidade de um indivíduo para consigo mesmo. Este convívio, no âmbito do direito civil, se pauta pelos direitos e deveres presentes no art. $1^{\circ}$ do Código Civil Brasileiro.

Ao tratarmos sobre a "sociabilidade", é importante entendermos o que ela significa. "Sociabilidade”, no Dicionário Escolar da Língua Portuguesa de 1983, significa “Qualidade do que é sociável; tendência para a vida em sociedade, modos de quem vive em sociedade." (BUENO, 1983, p. 1066).

Quando tratamos do princípio da sociabilidade no âmbito do Código Civil de 2002, estamos falando de um princípio que é caracterizado por ser aquele que garante a aplicação dos valores da coletividade sobre cada um dos indivíduos, observando os direitos fundamentais da pessoa humana. Um exemplo da aplicação desse princípio pode ser encontrado no princípio da função social do contrato e da propriedade. (BERTOCCO, 2008).

O significado de sociabilidade no Código Civil de 2002 vai de acordo com o significado discricionário dado pelo Dicionário supracitado, uma vez que em ambas as situações, está se privilegiando o caráter social e coletivo desse princípio.

Assim, para a legislação brasileira atual, o princípio da sociabilidade exprime a noção de que os interesses sociais estão em um patamar superior aos individuais. Aqui, visa-se o interesse da coletividade, da sociedade.

Ao analisarmos a legislação brasileira, percebemos a concretização desse princípio no art. $1.228, \S 1^{\circ}, \S 2^{\circ}$ e $\S 3^{\circ}$ do Código Civil de 2002. Vejamos o que diz a Lei:

Art. 1.228. O proprietário tem a faculdade de usar, gozar e dispor da coisa, e o direito de reavê-la do poder de quem quer que injustamente a possua ou detenha.

$\S 1^{\circ} \mathrm{O}$ direito de propriedade deve ser exercido em consonância com as suas finalidades econômicas e sociais e de modo que sejam preservados, de conformidade com o estabelecido em lei especial, a flora, a fauna, as belezas naturais, o equilíbrio ecológico e o patrimônio histórico e artístico, bem como evitada a poluição do ar e das águas.

$\S$ 2응 São defesos os atos que não trazem ao proprietário qualquer comodidade, ou utilidade, e sejam animados pela intenção de prejudicar outrem.

$\S 3$ - O proprietário pode ser privado da coisa, nos casos de desapropriação, por necessidade ou utilidade pública ou interesse social, bem como no de requisição, em caso de perigo público iminente. (Grifo nosso).

Com efeito, pode-se entender do princípio da sociabilidade que qualquer uma das categorias civis passa a ter função social, como a família, a posse, a empresa, o contrato, a responsabilidade civil e até mesmo a propriedade. 
Portanto, embasados pela conceituação de Miguel Reale sobre o princípio da sociabilidade, conceituamos esse princípio na nova codificação como uma forma de superação do caráter individualista e egoísta da legislação anterior, o Código Civil de 1916, pois a partir do novo código vigente, o sujeito “eu” passa ser substituído pelo "nós”. (TARTUCE, 2011, p. 23).

Posto isso, percebe-se a necessidade do balizamento legal das condutas civis no tocante ao comportamento social, para que se consagre a efetiva busca por uma sociedade fraterna.

\subsection{Princípio da Operabilidade}

A antiga legislação civil brasileira, qual seja, o Código Civil de 1916, apenas prestigiava as formalidades de cada um dos integrantes da relação jurídica, não aceitava a especificidade e a concretude de cada indivíduo. Ele igualava a todos e ignorava as particularidades de cada ser humano nas relações jurídicas. A norma era aplicada de maneira genérica, independentemente do caso em questão. (FARIAS, ROSENVALD, 2011, p. 56).

Já o Código Civil de 2002 adotou outra postura em relação à maneira de tratar o homem, que passa a ser visto como um ser central no ordenamento jurídico constitucional.

O Código faz questão de frisar que diferentemente do que acontecia nas antigas codificações, onde o indivíduo era tratado de forma abstrata, agora ele é visto como um ser concreto, que será minunciosamente examinado em todas as suas peculiaridades, um ser distinto. (FARIAS, ROSENVALD, 2011, p. 57).

A partir desse mero expediente, podemos visualizar o acerto do legislador a inserir o termo "pessoa" ainda no primeiro artigo do Código Civil de 2002, quando ele afirma que "toda pessoa é capaz de direitos e deveres na ordem civil".

Sobre a concretude, esta se dá por meio da operabilidade, que se concretiza por meio de encontrar formas céleres de solucionar as pretensões jurídicas, bem como através de mecanismos que "evitem a eternização de incertezas e conflitos". 
A respeito do princípio da operabilidade, a citar o jurista Miguel Reale, Flávio Tartuce manifesta em sua obra, Manual de Direito Civil, que tal princípio possui dois sentidos:

(i) $\mathrm{O}$ primeiro sentido seria o da simplicidade ou da facilitação das categorias privadas;

(ii) $\mathrm{O}$ segundo sentido seria de efetividade ou concretude, que foi consagrado a partir do sistema de cláusulas gerais que foi adotado pelo Código Civil de 2002.

(TARTUCE, 2011, p. 23).

$\mathrm{Na}$ legislação brasileira, o artigo do Código Civil de 2002 que melhor ilustra tal princípio, no que se refere à aplicabilidade da lei, é o artigo 1.228 , em seus parágrafos $4^{\circ}$ e $5^{\circ}$; vejamos:

Art. 1.228. "O proprietário tem a faculdade de usar, gozar e dispor da coisa, e o direito de reavê-la do poder de quem quer que injustamente a possua ou detenha. $\S 40$ O proprietário também pode ser privado da coisa se o imóvel reivindicado consistir em extensa área, na posse ininterrupta e de boa-fé, por mais de cinco anos, de considerável número de pessoas, e estas nela houverem realizado, em conjunto ou separadamente, obras e serviços considerados pelo juiz de interesse social e econômico relevante.

§ 5o No caso do parágrafo antecedente, o juiz fixará a justa indenização devida ao proprietário; pago o preço, valerá a sentença como título para o registro do imóvel em nome dos possuidores.

Assim, pode-se dizer que o atual objetivo do ordenamento jurídico é o de atingir a pessoa como a destinatária direta da norma, de modo que, para tanto, o legislador não se utiliza mais do preciosismo gramatical da norma, mas sim da sua efetividade na sua aplicação, de modo a primar pela executividade e praticidade.

Portanto, podemos afirmar categoricamente que o Código Civil de 2002 objetiva expurgar qualquer tipo de conceituação estéril não efetiva. (FARIAS, ROSENVALD, 2011, p. 57).

Tal entendimento demonstra que o direito posto pelos indivíduos no processo democrático e legal já leva em consideração que, em determinadas circunstâncias, analisadas em conformidade ao caso concreto, o direito individual abre espaço para o direito de um grupo de pessoas ou da coletividade. Como o tratamento fraterno enseja um grau de sacrifício individual, ainda que em abstrato, com fim de garantir o bem dos semelhantes, nota-se que o disposto no art. "I" da Declaração Internacional dos Direitos Humanos (ASSEMBLÉIA GERAL DA ONU, 1948) se efetiva pela operabilidade no direito civil. 


\section{OS PRINCÍPIOS FUNDAMENTAIS NORTEADORES DO DIREITO CIVIL PORTUGUÊS}

Diferentemente do direito civil brasileiro, o direito civil português possui uma gama maior de princípios. Contudo, diante do que será exposto a seguir, pode-se auferir que alguns princípios do ordenamento civil português guardam uma relação ainda mais substancial com os elementos da fraternidade.

\subsection{O Princípio da Personificação Jurídica do Ser Humano}

Luís A. Caravalho Fernandes, em sua obra Teoria Geral do Direito Civil, introduz o princípio da personificação jurídica do homem como o primeiro dos princípios fundamentais do Direito Civil português. (FERNANDES, 2015, p. $81)$.

Esse princípio pode ser considerado como "o princípio dos princípios", uma vez que ele reconhece a personalidade jurídica do homem e enxerga o homem como ponto central de todo o Direito.

Tal concepção é classificada como humanista, de forma que o indivíduo e todos os seus direitos que lhe foram outorgados são tidos como "o ponto mais alto do tratamento dos conflitos e interesses". (FERNANDES, 2015, p. 81).

O personalismo ético tem raiz estóica e cristã e tem como característica ser comum a todos os ramos do Direito, não sendo um atributo único do Direito Civil. (VASCONCELOS, 2015, p. 11).

O princípio da personificação jurídica do homem trata o indivíduo como um ser autônomo, livre e irreparável, tido como o elemento central de qualquer organização social. A sua dignidade é intrínseca desde a sua formação inicial.

Essa dignidade está proibida de ser, de alguma forma, reduzida, extinta ou alienada e ela jamais poderá ser valorada entre as pessoas, isso significa dizer que ela é indistinta para todas as pessoas.

Tal princípio veda qualquer forma de preconceito, seja ele racial, religioso, de gênero, classe ou qualquer que seja a forma de discriminação social, bem como proíbe qualquer tipo de restrição, exclusão ou privação de sua intrínseca qualidade de pessoa jurídica em relação a outro indivíduo, seja ele quem for. (FERNANDES, 2015, p. 83). 
A partir dos ensinamentos trazidos pelo código civil português, cabe ressaltar que o princípio da personificação jurídica do homem ou do ser humano é um pressuposto inderrogável.

Deveras, a personalidade é algo intrínseco à pessoa humana. Partindo dessa premissa, é de se afirmar que ela jamais poderá ser limitada, alienada ou condicionada a algo. Assim, quem quer que seja e estiver vivo jamais poderá abrir mão dela. A personalidade só se extingue com a morte.

Com efeito, qualquer pessoa nascida com vida adquirirá personalidade jurídica, de modo que não existe uma pessoa viva sequer que não tenha, aos olhos do Direito, personalidade jurídica. É o que expressam os artigos $66 .^{\circ} \mathrm{e}$ $68^{\circ}$ do Código Civil; vejamos:

\section{Artigo $66 .^{\circ}$ (Começo da personalidade)}

1. A personalidade adquire-se no momento do nascimento completo e com vida

2. Os direitos que a lei reconhece aos nascituros dependem do seu nascimento.

Artigo 69. (Renúncia à capacidade jurídica)

Ninguém pode renunciar, no todo ou em parte, à sua capacidade jurídica.

Portanto, a partir do reconhecimento e constatação de que personalidade é inerente à natureza do homem, o Direito Civil dá a sua principal colaboração para o Direito em geral. (VASCONCELOS, 2015, p. 11).

Diante do exposto, fica caracterizado o tratamento civil do indivíduo ante a sociedade, de modo que esteja garantido para cada pessoa o seu reconhecimento jurídico como membro da fraternidade social, como ser dotado de direitos e deveres impostos pelo ordenamento civil português.

\subsection{O Reconhecimento dos Direitos da Personalidade}

O princípio do reconhecimento dos direitos da personalidade é uma consequência do princípio fundamental da personificação jurídica do homem.

Entretanto, o simples reconhecimento do homem como um ser constituído de dignidade não seria o suficiente para que esse pudesse realizar de forma plena todos os seus interesses, mas a partir do reconhecimento de que o homem possui personalidade jurídica, que ele pode exercer todos os direitos jurídicos. (FERNANDES, 2015, p. 84).

Os direitos da personalidade têm a virtude de ser determinados pelo modo fundamental de ser de cada uma das pessoas. A Constituição portuguesa prevê, implicitamente, em sua Parte I, ao falar dos direitos e deveres 
fundamentais, a consagração do direito da personalidade. (FERNANDES, 2015, p. 85).

Portanto, pode-se afirmar que a dignidade da pessoa humana é amparada no ordenamento jurídico português tanto pelo princípio da personalidade quanto pelo da personificação do homem, atributo que se coloca em consonância com o disposto na DUDH, art. "I" (ASSEMBLÉIA GERAL DA ONU, 1948), como elemento constitutivo do indivíduo habilitado a exercer um convívio em condições de fraternidade.

\subsection{O Princípio da Igualdade da Pessoa Humana Perante a Lei e na Lei}

Os princípios fundamentais do direito civil anteriormente citados dão amparo à dignidade da pessoa humana, uma vez que estes garantem que ela é indistintamente inerente a todos os homens. (FERNANDES, 2015, p. 86).

Com efeito, não seria diferente a respeito do princípio da igualdade dos homens perante a lei, uma vez que ele reconhece a dignidade como algo em comum para ser aplicado a todos os homens.

Partindo para uma análise do princípio da igualdade do homem perante a lei, o atual código civil português, apesar de não ter expressamente acolhido esse princípio, o consagrou em seu sistema jurídico, diferentemente do que aconteceu na Constituição Política de 1933, que apesar de citar o princípio da igualdade em seu artigo $5 .^{\circ}$, § único, fazia diferenciação na aplicação prática desse princípio quanto ao gênero, pois condicionava a sua aplicação para as mulheres nos seguintes termos:

O Estado português é uma" República unitária e corporativa, baseada na igualdade dos cidadãos perante a lei, no livre acesso de todas as classes aos benefícios da civilização e na interferência de todos os elementos estruturais da Nação na vida administrativa e na feitura das leis.

§único - A igualdade perante a lei envolve o direito de ser provido nos cargos públicos, conforme a capacidade ou serviços prestados, e a negociação de qualquer privilégio de nascimento, nobreza título nobiliárquico, sexo ou condição social, salvas, quanto à mulher, as diferenças resultantes da sua natureza e do bem da família, e, quanto aos encargos ou vantagens dos cidadãos, as impostas pela diversidade das circunstâncias ou natureza das coisas. (grifo nosso).

Assim, apesar de a Constituição de 1933 citar o princípio da igualdade perante a lei, esta continha ressalvas para sua aplicação. 
Já a atual Constituição da República Portuguesa de 1976 não condiciona a nada a aplicação do princípio da igualdade, uma vez que ela estabelece que este princípio deve ser aplicado a todos os cidadãos, sem nenhum tipo de restrição. Vejamos:

“Artigo 13.” Princípio da igualdade

1. Todos os cidadãos têm a mesma dignidade social e são iguais perante a lei.

2. Ninguém pode ser privilegiado, beneficiado, prejudicado, privado de qualquer direito ou isento de qualquer dever em razão de ascendência, sexo, raça, língua, território de origem, religião, convicções políticas ou ideológicas, instrução, situação económica, condição social ou orientação sexual".

Outrossim, cabe salientar que em seu artigo $9^{\circ}$, a atual Constituição da República Portuguesa de 1976 vislumbra um regime igualitário concreto e real entre os seus cidadãos, uma vez que estabelece que "é uma das tarefas fundamentais do Estado a promoção da igualdade real entre os portugueses" (FERNANDES, 2015, p. 87).

Destarte, o princípio da igualdade ganha real efetividade quando é assegurado aos desiguais o tratamento desigual, na medida de suas desigualdades, para que a igualdade seja atingida.

Isso, por exemplo, ocorre com as pessoas portadoras de necessidades especiais, pois lhes são atribuídos, em disposições legais, "benefícios" que lhes garantam direitos que viabilizem o exercício de condições de igualdade com pessoas não portadoras de necessidades especiais.

Assim, vale reiterar o que foi dito anteriormente; o princípio da igualdade se presta para garantir que toda pessoa humana seja tratada com dignidade, uma vez que ele garante a igualdade aos desiguais, na medida de suas desigualdades.

Posto isso, pode-se auferir que este princípio se coloca como um elemento de obrigação de tratamento, pelos moldes fraternos, do indivíduo pelos demais membros da sociedade.

\subsection{O Princípio do Reconhecimento da Família como Instituição Fundamental}

Faz parte da "maneira de ser" do Direito Civil português o princípio do reconhecimento da família como instituição fundamental da sociedade. A 
assertiva se justifica porque a família é a célula social onde se inicia o amadurecimento da vida dos indivíduos. (FERNANDES, 2015, p. 92).

É na família que se desenvolve o modo de ser das gerações passadas e futuras, que dão seguimento à vida em sociedade. Por essa razão o Direito busca, em primeiro lugar, parâmetros que reconheçam a família como uma instituição.

Para o Direito português, a família possui o status de elemento fundamental da sociedade e possui proteção constitucional; prova disso está nos artigos da Constituição da República Portuguesa de 1976 a seguir aduzidos:

\section{Artigo $67 .^{\circ}$}

Família

1. A família, como elemento fundamental da sociedade, tem direito à protecção da sociedade e do Estado e à efectivação de todas as condições que permitam a realização pessoal dos seus membros.

2. Incumbe, designadamente, ao Estado para protecção da família:

a) Promover a independência social e económica dos agregados familiares; b) Promover a criação e garantir o acesso a uma rede nacional de creches e de outros equipamentos sociais de apoio à família, bem como uma política de terceira idade;

c) Cooperar com os pais na educação dos filhos;

d) Garantir, no respeito da liberdade individual, o direito ao planeamento familiar, promovendo a informação e o acesso aos métodos e aos meios que o assegurem, e organizar as estruturas jurídicas e técnicas que permitam o exercício de uma maternidade e paternidade conscientes;

e) Regulamentar a procriação assistida, em termos que salvaguardem a dignidade da pessoa humana;

f) Regular os impostos e os benefícios sociais, de harmonia com os encargos familiares;

g) Definir, ouvidas as associações representativas das famílias, e executar uma política de família com carácter global e integrado;

h) Promover, através da concertação das várias políticas sectoriais, a conciliação da actividade profissional com a vida familiar.

Deveras, cabe salientar que a família foi protegida pelo legislador quando este reconheceu no art. $67^{\circ} \mathrm{o}$ dever de assegurar a proteção desta e de assegurar a realização pessoal de seus membros.

\section{Artigo $36 .^{\circ}$}

Família, casamento e filiação

1. Todos têm o direito de constituir família e de contrair casamento em condições de plena igualdade.

2. A lei regula os requisitos e os efeitos do casamento e da sua dissolução, por morte ou divórcio, independentemente da forma de celebração.

3. Os cônjuges têm iguais direitos e deveres quanto à capacidade civil e política e à manutenção e educação dos filhos.

4. Os filhos nascidos fora do casamento não podem, por esse motivo, ser objecto de qualquer discriminação e a lei ou as repartições oficiais não podem usar designações discriminatórias relativas à filiação.

5. Os pais têm o direito e o dever de educação e manutenção dos filhos.

6. Os filhos não podem ser separados dos pais, salvo quando estes não cumpram os seus deveres fundamentais para com eles e sempre mediante decisão judicial. 
$\mathrm{O}$ artigo constitucional $36^{\circ}$ acima transcrito ressalta o reconhecimento da família como elemento fundamental da sociedade, assegurando às pessoas o direito de se casar e constituir família, se assim desejarem, bem como assegura a igualdade de tratamento às famílias não constituídas pelo matrimônio, mas pela união de fato, bem como reconhece o caráter laico do casamento. (FERNANDES, 2015, p. 93).

Dar-se-ia então, por intermédio da família, o seio primário da relação social humana, um ambiente favorável para o desenvolvimento da fraternidade do indivíduo, pois nesse âmbito as experiências de relação fraterna, o tratamento entre irmãos, pais, filhos, como iguais, dão ensejo à compreensão, mesmo que rudimentar, de como a pessoa deve exercer suas condutas, levando em consideração algo maior do que a percepção de si mesmo, a percepção de um modo de viver social.

\subsection{A Consagração do Princípio da Autonomia da Vontade ou Privada}

O poder da consagração do princípio da autonomia da vontade ou da vontade privada tem espaço no Direito Privado, uma vez que ele é o campo onde os indivíduos realizam as suas liberdades individuais, civis, contratuais e de personalidade. (FERNANDES, 2015, p. 94).

Como princípio característico do Direito Civil, a autonomia privada é consequência do princípio da liberdade, que representa o conceito de que tudo aquilo que não é ilícito, é lícito.

O princípio da autonomia privada é contraposto ao princípio da competência, proveniente do Direito Público, que delimita a licitude apenas às coisas legalmente permitidas.

Para o Direito Civil português, o princípio da autonomia privada abarca, subjetivamente, a vontade individual, onde os interesses de cada um são realizados no âmbito das relações entre particulares, de modo que os particulares têm a faculdade de dispor ou não sobre as suas vontades, pois possuem autonomia própria para tanto.

Pode-se dizer, então, que o princípio da autonomia da vontade ou da vontade privada está no “poder de livre exercício dos direitos pelo seu titular”. (FERNANDES, 2015, p. 95).

No entanto, na atual conjuntura do Direito Civil português, existe a predominância da ideia de que não existe direito subjetivo absoluto, uma vez que esses direitos devem atingir fins econômico-sociais, o que acaba por esbarrar nas esferas do individualismo da autonomia.

Ademais, cabe esclarecer que os direitos subjetivos muitas vezes acabam pondo em risco a segurança de outras pessoas ou dela própria. Assim, é possível se afirmar que existe um limite à autonomia da vontade privada, uma vez que o direito do possuidor da autonomia pode ser abusivo, e o Direito Civil não reconhece, em sua ordem jurídica, tutela a condutas eivadas de abusividade. 
Deveras, o direito subjetivo passou a ser funcionalizado, uma vez que não é mais apenas a vontade do indivíduo a que prevalece no princípio da autonomia da vontade privada, mas a função social das atividades que este irá desempenhar, pois tal princípio também prima pelos interesses da coletividade.

Cabe esclarecer que o princípio da autonomia privada tem maior reconhecimento e efetividade no plano negocial, ou seja, no plano dos contratos, na liberdade contratual, uma vez que é por meio dos contratos que a autonomia privada produzirá efeitos jurídicos. (FERNANDES, 2015, p. 96).

Desta forma, pode-se aduzir que o direito civil português leva em conta, por um princípio, o aspecto da função social, da utilidade fraterna, mesmo em âmbito privado. Este elemento, de consideração do coletivo, é característico de uma sociedade fraterna, em conformidade com o art. "I" da Declaração Universal dos Direitos Humanos (ASSEMBLÉIA GERAL DA ONU, 1948).

\subsection{O Princípio da Consagração da Responsabilidade Civil}

Estendendo o entendimento de que o privado deve exercer sua função social para consagração da sociedade fraterna, no exercício dessa função se dá o princípio da consagração da responsabilidade civil, que se efetiva quando os danos causados a outrem são reparados por quem efetivamente causou esses danos.

A liberdade sempre esteve atrelada ao que se entende pela concretização da responsabilidade civil, uma vez que quando se reconhece o direito das pessoas à liberdade para fazerem o que quiserem, estas também terão que responder pelas suas consequências.

Outrossim, o agente causador de um dano terá que responder civilmente por tais danos causados, independentemente desses danos terem sido causados por vontade do agente (dolo), por negligência ou até mesmo por culpa (diligência exigível). (FERNANDES, 2015, p. 97).

Devido a fenômenos ligados à ampliação do desenvolvimento tecnológico, social e comercial, o conceito de responsabilidade civil se alargou e passou a ser mais rigoroso nas relações jurídicas e subjetivas de modo a surgirem novas modalidades de responsabilidade civil, pelas quais até atividades consideradas como lícitas passaram a ser passivas de responsabilização por danos que tais atividades pudessem causar.

Como nos casos das relações de consumo, nas quais um produto adquirido pelo consumidor venha a possuir um vício ou nos casos em que uma atividade comercial cause danos ao meio ambiente (situação particular que deu ensejo para a promulgação do Decreto-Lei n. ${ }^{\circ}$ 174/2008). (FERNANDES, 2015, p. 98). 
Em relação à cobertura do dano causado a outrem, a responsabilidade civil evoluiu, uma vez que para as situações em que não seja possível averiguar quem causou um mal por meio de uma atividade lícita, surge a figura dos seguros - obrigatórios ou facultativos - como forma de ressarcir a pessoa que sofreu o dano causado por uma atividade lícita.

Assim, a partir dessas novas relações jurídicas, surge uma necessidade cada vez maior de garantir a efetividade da reparação dos danos eventualmente causados, seja por meio do seguro obrigatório ou facultativo, seja pela intervenção do Estado nessas relações, sendo ele o responsável por reparar o prejuízo causado a outrem. Dessa maneira, fica constatado o que o civilista Almeida Costa chama de "socialização do dano". (FERNANDES, 2015, p. 99).

A responsabilização pelo dano contribui para a sociedade fraterna, em especial no prisma do pensamento da tutela de um por todos e todos por um. Quando se dá a aplicação deste princípio, se consubstancia o dever do indivíduo perante aos outros, e o cumprimento da cota parte individual, em termos de responsabilidade, é essencial para o alcance de uma sociedade fraterna de fato.

\subsection{O Reconhecimento do Princípio da Propriedade Privada}

Para falarmos sobre o princípio da propriedade privada, precisamos primeiramente entender o que propriedade significa para a Teoria Geral e os princípios fundamentais do Direito Civil. Nesse contexto, ela tem significado de identificação e reconhecimento dos direitos patrimoniais, “direito real de gozo máximo”. (FERNANDES, 2015, p. 100).

A atual Constituição da República Portuguesa assegura o direito à propriedade privada em seu art. $62^{\circ}, n^{\circ} 1$; vejamos:

\section{Artigo $62 .^{\circ}$}

Direito de propriedade privada

1. A todos é garantido o direito à propriedade privada e à sua transmissão em vida ou por morte, nos termos da Constituição.

Em relação ao conteúdo do direito de propriedade privada, o artigo $1305 .^{\circ}$ do Código Civil prevê o direito real pleno da propriedade; vejamos:

\footnotetext{
Artigo $1305^{\circ}$ - Conteúdo do direito de propriedade

O proprietário goza de modo pleno e exclusivo dos direitos de uso, fruição e disposição das coisas que lhe pertencem, dentro dos limites da lei e com observância das restrições por ela impostas.
}

A Declaração Universal dos Direitos Humanos também trata da propriedade privada no seu artigo "XVII" (ASSEMBLÉIA GERAL DA ONU, 1948), garantindo que esse direito seja assegurado em oposição a quem queria feri-lo. Pode-se dizer que uma sociedade fraterna 
age em conjunto para proteger os direitos individuais, dentre os quais figura o direito de propriedade, direito esse que se consolida pela função social, como tratado anteriormente.

\subsection{O Princípio do Reconhecimento ao Direito Sucessório a Todos os Herdeiros}

O princípio do reconhecimento ao direito sucessório a todos os herdeiros é uma consequência da consagração do reconhecimento da propriedade privada. Ele é proveniente dos Direitos das Sucessões e se manifesta a partir do reconhecimento do que se conhece no Direito português por mortis causa. (FERNANDES, 2015, p. 103).

O advento do instituto da mortis causa tem previsão legal no supracitado artigo 62. , n. ${ }^{\circ} 1$ do Código Civil.

O fenômeno sucessório é classificado pela doutrina portuguesa em três sistemas fundamentais sucessórios: a) o capitalista (cuja visão é constitucionalista, isto é, de acordo com a proximidade com o texto constitucional, onde se reconhece a propriedade privada e o fenômeno sucessório), b) o familiar e c) o socialista.

No entanto, o Direito das Sucessões é visto pela lei portuguesa como um sistema misto, sendo uma consequência lógica dos três fenômenos supracitados.

Com efeito, quando se trata de sucessão legitimária, é importante destacar o papel que o cônjuge tem nesse instituto, uma vez que ele é um dos principais sucessíveis legitimários, concorrendo igualmente com os herdeiros descendentes e ascendentes.

Cabe salientar que a inclusão do cônjuge na lista dos principais sucessíveis legitimários é recente e aparece como forma de ressaltar a importância do instituto da família no fenômeno sucessório. (FERNANDES, 2015, p. 105).

Logo, esse princípio surge como uma consagração da tutela principiológica da propriedade privada e da proteção da família, cuja proteção é inerente a todos, uma vez que o exercício da vida em plenitude de direitos e compromissada com os deveres sociais é fundamental para a consolidação da sociedade fraterna.

\subsection{O Princípio do Reconhecimento da Personalidade Jurídica às Pessoas Coletivas}

A personalidade jurídica coletiva se dá no momento em que existe uma generalidade de pessoas que se projetam no tempo e ultrapassam a duração da vida do homem. Ela pode existir tanto no campo do Direito Público quanto no campo do Direito Privado. (FERNANDES, 2015, p. 91).

A norma constitucional fala da personalidade jurídica coletiva em seu art. $12 .^{\circ}$, n. $^{\circ} 2$; vejamos: 
Princípio da universalidade

1. Todos os cidadãos gozam dos direitos e estão sujeitos aos deveres consignados na Constituição.

2. As pessoas colectivas gozam dos direitos e estão sujeitas aos deveres compatíveis com a sua natureza.

Com efeito, há de se reconhecer nesse princípio que cada uma das pessoas coletivas possui individualidade própria, uma vez que o texto constitucional determina que os direitos de gozo dessas pessoas estão sujeitos aos deveres compatíveis com a sua natureza. (FERNANDES, 2015, p. 91).

Por fim, temos o princípio que trata do desempenho da sociabilidade do indivíduo na busca por um fim social. Fora do seio familiar e do convívio social comum, os indivíduos se reúnem para executar um determinado trabalho, para a entrega à sociedade de um produto ou serviço necessário. O desempenho regular da fraternidade se consolida de forma mais efetiva na formação de entes de personalidade jurídica formados pela unificação do trabalho de vários indivíduos.

A junção do exercício social, com o cumprimento de deveres, nos limites dos direitos individuais e no desempenho da função social pode caracterizar muito bem a fraternidade enquanto um princípio e fim. Em conformidade com o disposto no art. "I" da Declaração Universal dos Direitos Humanos (ASSEMBLÉIA GERAL DA ONU, 1948).

\section{CONSIDERAÇÕES FINAIS}

Conforme se pretendeu demonstrar, pode-se perceber que os princípios presentes nos códigos civis de Portugal e do Brasil remontam, cada um de uma maneira, ao objetivo de fraternidade social inserido na Declaração Universal dos Direitos Humanos.

Por sua natureza de reforço interpretativo, a fraternidade se consagra como um balizador da aplicação do direito, especialmente pelos operadores do direito civil, no caso em tela: as condutas desempenhadas pelos indivíduos.

Soa razoável que mesmo diante de uma lide cuja origem se dá por um litígio de extenso dano social, os códigos civis remontem ao objetivo social da fraternidade, constrangendo judicialmente o caso subjetivamente controverso no mais pacificamente fraternal possível, dando a solução fraterna e justa para o caso concreto.

Dessa forma, conforme o demonstrado, conclui-se que a fraternidade em abstrato, reforçada pelo preâmbulo da constituição de cada um dos países, flui pelo ordenamento jurídico em consonância com princípios norteadores do direito civil. 


\section{REFERÊNCIAS BIBLIOGRÁFICAS}

ALEXY, Robert. Teoria dos Direitos Fundamentais. Trad. Virgílio Afonso da Silva. São Paulo: Malheiros, 2011.

ASSEMBLÉIA GERAL DA ONU. (10 de dezembro de 1948). DUDH 2019. Disponível em:

$<$ https://nacoesunidas.org/wpcontent/uploads/2018/10/DUDH.pdf $>$ Acesso em: 30 set. 2019.

BERTOCCO, Ciara. Quais são os princípios norteadores do Código Civil de 2002? CJusbrasil. 2008. Disponível em:

$<$ http://1fg.jusbrasil.com.br/noticias/24493/quais-sao-os-principiosnorteadores-do-codigo-civil-de-2002-ciara-bertocco $>$. Acesso em: 30 set. 2019.

BRASIL. Constituição, 1988. Constituição da República Federativa do Brasil de 1988. Senado Federal. Disponível em:

$<$ http://www.planalto.gov.br/ccivil_03/Constituicao/Constituicao.htm>. Acesso em: 22 set. 2019.

BRITTO, Carlos Ayres. Ética em verso e por prosa. CREA-SE. 2013. Disponível em: <http://www.crea-se.org.br/etica-em-verso-e-prosa/>. Acesso em: 30 set. 2019 .

BUENO, Francisco da Silveira - Dicionário Escolar da Língua Portuguesa. $11^{\mathrm{a}}$. ed. Rio de Janeiro: Ministério da Educação e Cultura Fundação Nacional de Material Escolar, 1983.

FERnANDES, L. A. C. Teoria Geral do Direito Civil. 6 ${ }^{a}$ ed. Lisboa: Universidade Católica Editora, 2015.

HENTZ, André Soares. Os princípios da eticidade, da socialidade e da operabilidade no Código Civil de 2002. Revista Jus Navigandi, Teresina. Disponível em: <https://jus.com.br/artigos/922>. Acesso em: 30 set. 2019.

REINEHR, Rosemeri. Os princípios orientadores do novo Código. Âmbito Jurídico, Rio Grande. Disponível em:

$<\mathrm{http}$ ://ambitojuridico.com.br/site/index.php/?n_link=revista_artigos_leitura\& artigo_id=13183\&revista_caderno=7>. Acesso em: 30 set. $20 \overline{1} 9$.

TARTUCE, Flávio - Manual de Direito Civil - Volume Único. Rio de Janeiro: Forense; São Paulo: Método, 2011. 